\title{
Las flores en el modernismo hispanoamericano
}

\author{
LILY LITVAK \\ Universidad de Texas-Austin
}

Título: Las flores en el modernismo hispanoamericano.

Resumen: El modernismo recurrió a las flores no solo por su belleza sino porque a través de ellas podían espiritualizar la materia. Las convirtió en símbolos en los que intervenían no solo los significados tradicionales sino nuevos valores aportados por la nueva sensibilidad. Las corrientes estéticas de fin de siglo: exotismo, prerrafaelismo, parnasianismo, simbolismo, decadentismo, influyeron en la valorización de ciertas flores, entre ellas, el crisantemo, la orquídea, la rosa, el loto, el lirio, como puede verse enla literatura y el arte del modernismo hispanoamericano.

Palabras clave: flores, modernismo, parnasianismo, exotismo, simbolismo, prerrafaelismo, decadentismo, literatura, arte, crisantemo, loto, orquídea, rosa, lirio, azucena.

Fecha de recepción: 14/2/2013.

Fecha de aceptación: 22/4/2013.
Title: Flowers in Hispanic Modernism.

Abstract: The Latin American Modernistas were inspired by certain flowers and endowed them with symbolic meanings, adding to their traditional meaning new values representative of the turn-of-the-century sensibility. Several aesthetic trends and movements - Exoticism, Pre-Raphaelism, Parnasianism, Symbolism, Decadentism determined their predilection for flowers like the chrysanthemum, the lotus, the rose, the orchid, the lily, as can be seen in their literature and art.

Key words: flowers, Modernismo, literature, art, exoticism, pre-Raphaelism, Parnasianism, Symbolism, Decadentism, chrysanthemum, lotus, rose, orchid, lily.

Date of Receipt: 14/2/2013.

Date of Approval: 22/4/2013.

Varias civilizaciones consagraron las flores como tema literario y artístico. Por ejemplo, figuran prominentemente en la pintura holandesa del siglo XVII y en la iconografía del arte japonés. Las asociaciones con las flores se extienden del simbolismo a la ciencia, de la poesía a la religión. Muchos 
nombres ilustres las acompañan; Linneo y su sistema taxonómico; Goethe, en busca de la urplanze; y Novalis de la flor azul; Emerson, paseando por el Jardin des Plantes de París; y cabe recordar aquí el título del libro de Baudelaire que tanto influyó durante el fin del siglo XIX: Las flores del mal.

Los modernistas acudieron a las flores por su belleza, pero sobre todo porque a través de ellas llevaban a cabo una espiritualización de la materia. Las convirtieron en símbolos en los que intervenía no solo la especie, sino también el color y forma de la corola, el vector del tallo, la inclinación de un pétalo, su lozanía y rareza. A las flores tradicionales agregaron aquellas que el fin de siglo descubrió y popularizó. A ello contribuyó la revalorización del paisaje en la pintura, el neogoticismo, que dio nueva vida a formas oscurecidas por la decoración clásica del Renacimiento, y la estilización floral llevada a cabo en las artes gráficas que valoraban la línea y el arabesco. Fue también fundamental la gran aceptación que a lo largo del siglo XIX tuvieron las ciencias botánicas y el cultivo de las flores, la difusión de la jardinería y el arreglo floral. Hay que notar también, desde principios del Ochocientos, la publicación de libros, sobre todo ingleses y franceses, como Flowers and Their Association (1840) de Anna Pratt, con información botánica y leyendas sobre flores; The Ladies Flower Garden of Ornamental Annuals (1849) de Mrs. Loudon; y Flora symbolica (1869) de John Henry Ingram, que presentaba una historia cultural y una lista alfabética de flores con su significado simbólico, siguiendo el ejemplo del best seller de Charlotte de La Tour Le Langage des fleurs (1819).

INFLUENCIAS LITERARIAS Y ESTÉTICAS

\section{Japonismo}

Gran parte de la iconografía floral del modernismo provenía de su atracción hacia culturas exóticas y, en particular, Japón, donde las flores eran tan veneradas que se consideraban "santas". La inspiración provino de la pintura nipona basada en las formas del mundo natural; aves, insectos, peces, flores "captados con todas sus caprichosas metamorfosis, 


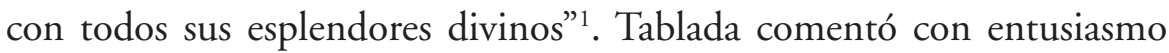
la influencia en Europa e Hispanoamérica de ese arte de intenso y sutil carácter que "avivó en los artistas el estudio de la flora y de la fauna mínima”, llevando nuevos elementos a la ornamentación y al decorado en donde sustituyeron "la eterna hoja de acanto de los capitales o la cara de león de las gárgolas clásicas" ${ }^{2}$. El diseño del arte japonés a base de líneas fuertes y espacios abiertos, o sin decoración, proponía un tratamiento muy poco convencional, en un momento en que imperaban las formas profusamente decoradas de la era victoriana. También orientó el gusto hacia composiciones asimétricas, opuestas a la simetría familiar a los europeos, aún comprometidos con el revival griego del siglo XIX.

\section{Prerrafaelismo}

El prerrafaelismo aportó al modernismo la predilección por ciertas especies, y la formulación de un lenguaje floral ${ }^{3}$. Dante Gabriel Rossetti se inspiraba en diversas fuentes, a menudo excéntricas, para su iconografía. Esas imágenes iban unidas a ideas, y no fue el único que hizo de ellas una expresión icónica. La práctica de otorgar un significado expresivo a cada flor, desde la más humilde hasta la más complicada y exótica, llevó a la fundación de la Hermandad Prerrafaelita por un grupo de artistas que estudiaban con atención la naturaleza, donde encontraban gran sinceridad. De allí la adopción del dictamen de Ruskin, "Truth to Nature", que orientó la corriente floral victoriana. Como afirmó Walter Pater, el aprecio que se tenía por esos pintores ${ }^{4}$ dependía de la familiaridad del espectador con el lenguaje esotérico de los símbolos. Y lamentaba que los ignorantes considerasen las flores como "estorbosos enigmas", sin entender que cada una de ellas representaba una parábola.

1 Enrique Gómez Carrillo, El Japón heroico y galante, Madrid, Mundo Latino, 1912, recogido en Obras Completas, Madrid, Mundo Latino, 1920, VII, p. 91.

2 José Juan Tablada, En el país del sol, Nueva York y Londres, Appleton y Cía, 1919, pp. 92-93.

3 Los antecedentes de esta costumbre se remontan a las descripciones del sélam turco que hicieron Lady Mary Wortley Montagu y Seigneur Aubry de la Mottraye tras su viaje a Turquía en los primeros años del siglo XVIII.

4 Debra N. Mancoff, Flora Symbolica. Flowers in Pre-Raphaelite Art, Munich, Berlin, London, NY, Prestel, 2003, p. 6. 


\section{Simbolismo}

El simbolismo concebía la naturaleza como punto de partida para expresar una visión interior, un estado de alma, o la revelación de la fuerza cósmica. El paisaje simbolista, a menudo dotado de cualidades oníricas o visionarias, era subjetivo y ajeno a propósitos meramente narrativos. Gustave Kahn, en su oposición al naturalismo, había definido en 1886 la meta del movimiento: "objetivar lo subjetivo (la exteriorización de una idea), en vez de subjetivar lo objetivo (la naturaleza vista a través de un temperamento)"'s.

El simbolismo prefería el misterio a la clarividencia, y en su exaltación de lo impreciso y lo vago propició la asociación de correspondencias ocultas. Las flores no eran solo metáforas, sino signos de la unidad primigenia del universo. El antirracionalismo de esta posición defendía aún lo que no se comprendía, pues se estimaba que una palabra "medio entendida” era mejor que su comprensión total. De allí que la expresión floral, forma esotérica de expresión simbólica, no necesitara doblegarse ante el lenguaje lógico.

\section{Parnasianismo}

Si por sentimiento y lirismo el modernismo apreciaba el fondo, un movimiento tan enamorado del arte no podía dejar de valorizar la forma, y la expresión fue motivo de especial interés. La mentalidad eminentemente aristocrática del Parnaso orientó la oposición al naturalismo y a la reproducción mimética de la naturaleza y otorgó a las flores un cincelado decorativismo que las integró en el mundo ideal de los vitrales, las pinturas, los relieves, las taraceas con incrustaciones de nácar y vidrios... Pero en las flores los modernistas unieron el amor a la forma verbal esculpida, cincelada, esmaltada, según el evangelio parnasiano, con la fuerza vital y el impulso irracional del simbolismo.

5 Robert Goldwater, Symbolism, New York, Harper \& Row Publishers, 1979, p. 1. 


\section{Decadentismo}

La desilusión de la armonía liberó la fantasía para investigar el inconsciente y lo extravagante. El decadentismo revisó los conceptos aplicados al fin de la civilización y los declinares de la Historia y los aplicó al individuo. Verlaine, uno de los íconos de este movimiento, identificaba en su poema "Langueur" el finis latinorum con un arte espléndido. Descartaba el uso tradicional del concepto de "decadencia" como caída o declive, sustituyéndolo por un juicio positivo, que hacía de esos períodos "instantes privilegiados para el apogeo de una civilización excepcional, brillante y refinada" . De ello derivó una estética basada en la exaltación de la belleza mórbida y la sensualidad enfermiza, el placer hallado en la propia destrucción, la complacencia morbosa en la tortura, y a la vez el desprecio por lo anodino y lo vulgar. El pensamiento esteticista incorporó la complacencia por el lujo, y el culto al artificio, a lo inútil y bello, elevándose el arte como valor fundamental, superior y mejor que la vida ${ }^{8}$.

\section{CuAtro Flores MODERNistas}

\section{Crisantemos}

La rama florida del cerezo, el jacinto, la anémona, la amapola, la camelia, la hortensia, la wisteria, la peonía, llegaron al modernismo a través del arte japonés. Pero el crisantemo, elegante y aristocrático, codiciado por las minorías, era la flor japonista por excelencia. En su gran novela, Proust describió el apartamento de Odette de Crécy, al que se llegaba por una escalera adornada con tapices, estatuas orientales y una jardinera con crisantemos de variadas formas y colores.

Fascinaba la variedad de especies; sus extraños colores en singulares

6 Publicado en Le Chat Noir el 26 de mayo de 1883. Incluido en Paul Verlaine, Jadis et naguère, París, L. Vanier, 1884, p. 104.

7 Begoña Sáez Martínez, Las sombras del modernismo. Una aproximación al Decadentismo en España, Valencia, Diputació de València, 2004, pp. 28-29.

8 Luis Antonio de Villena, "El camino simbolista de Julián del Casal", en El Simbolismo, ed. José Olivio Jiménez, Madrid, Taurus, 1970, pp. 111-125. 
y apagados tonos y sus corolas complicadas; llenas o descabelladas, con pétalos retorcidos y serpenteantes, o en forma de arañas. No parecían seres naturales, sino exóticos objetos artísticos, como las japonerías que habían invadido y fascinado a Europa desde mediados de siglo. Gómez Carrillo quedó extasiado ante los crisantemos “divinos” del Japón, desplegados al lado de lacas, marfiles, jades, bronces, sedas, filigranas ${ }^{9}$. Algunos modernistas, siguiendo el ejemplo de Pierre Loti, en Mme Chrisantème, vincularon la flor con la artificiosidad de la mujer japonesa. Así lo hizo Darío en "Divagación", donde recorre una geografía erótica, cultural y exotista, y enmarca a una geisha "en su labrado camarín de plata / ornado al par de crisantemo y loto" 10 .

\section{Lotos}

El loto (nelumbo nucifera), sagrado en Egipto e India, ocupó lugar de honor en el jardín modernista. Tenía varios significados: pureza, belleza, majestad; aludía a la meditación y era evocador de lugares y religiones lejanas, con su corola compuesta por pétalos concéntricos que afloran a la superficie. Julián del Casal contempla la flor nocturna:

De la Luna al claro brillo

iría al Río Amarillo

a esperar

la hora en que, el botón roto,

comienza la flor de loto

a brillar ${ }^{11}$.

Tablada, en un homenaje a Hokusai, imagina al pintor sentado en una gigantesca flor de loto, "como un Budha"12. Esta mención podrían

9 Enrique Gómez Carrillo, op. cit., pp. 89-90.

10 Rubén Darío, Prosas Profanas (1896), Madrid, Espasa Calpe, 1972, p. 22. Sobre este tema cf. mi artículo "Japonerías. El objeto japonés en el fin de siglo", Siglo XIX, 17, 2011, pp. 237-278.

11 Julián del Casal, "Nostalgias", en Poesías completas, ed. Mario Cabrera Saqui, La Habana, Publicaciones del Ministerio de Cultura, 1945, p. 221.

12 Juan José Tablada, "El poema de Hokusai", en Los mejores poemas de Juan José Tablada, México, Editorial Surco, 1943, p. 70. 
describir el salón de Lugones, decorado con un Budha de ocho brazos y ocho piernas que descansaba entre lotos ${ }^{13}$.

Era la flor mística que Gómez Carrillo había admirado en Japón, flotando "orgullosamente en los estanques de los parques"; la que convertía "en senderos floridos los fosos de los castillos feudales"14. Amado Nervo, en El estanque de los lotos, también reveló su atracción por el budismo, aunque a veces varía el contexto. Y en "Esquifes" le atrae la naturaleza inmarcesible del "loto que en el agua se copia, mas cuya corola no toca el agua"; sin olvidar las referencias clásicas cuando menciona el "pálido loto del olvido"15.

\section{Lirios y azucenas}

El iris (o lirio) azul y el morado (Iris germanica) fueron casi un emblema del modernismo. Era la misteriosa flor puesta de moda por Grasset que brota en los broches de Lalique, y en la poesía de Jean Lorrain. Gutiérrez Nájera menciona desde temprano al "lirio azul que dormita en la ventana"16. Gómez Carrillo admiró en Japón "los esbeltos iris" que crecen en jardines y montañas, y los campos inmensos de iris con multitud de matices azulados. Se deleitaba ante sus complicadas formas; el arabesco de sus sinuosos pétalos, sus largos tallos y hojas como espadas, que aparecen, entre dragones y quimeras con alas de fuego, tallados en la arquitectura de los templos, labrados en los capiteles, esmaltado en los muros de laca, concluyendo que los japoneses que tan horribles muecas dan a los animales, "saben prestar a las plantas seducciones desconocidas en el resto del mundo" 17 .

Del prerrafaelismo llegó la popularidad del iris o lirio blanco. Sarah Bernhardt se rodeaba con ellos, a modo de símbolo ideal para

13 Maria Pía López, Lugones entre la aventura y la cruzada, Buenos Aires, Colihue, 2004, p. 48.

14 Enrique Gómez Carrillo, op. cit., p. 174.

15 Amado Nervo, "Inmortalidad", en En Voz baja, Obras Completas, Madrid, Aguilar, 1955-1956, II, p. 1565; "Los esquifes", en Cuentos y crónicas de Amado Nervo México D.F., Universidad Nacional Autónoma de México, 1993, pp. 10-11.

16 Manuel Gutiérrez Nájera, "Después de las carreras”, en Cuentos frágiles (1883), ed. Francisco Monterde, Cuentos y cuaresmas del Duque Job, México, Editorial Porrúa, 1972, p. 29.

17 Enrique Gómez Carrillo, op. cit., pp. 172-173. 
La Dame aux camélias, puesto que esta flor representa la virginidad reencontrada. Darío la menciona como caracterización de la mujerflor-lirio. Carolina, en "De invierno", es "como una rosa roja que fuera flor de lis"; y en "El poeta pregunta por Stella” describe: "Lirio, boca de nieve donde sus dulces labios / la primavera imprime: / en tus venas no corre la sangre de las rosas pecadoras, / sino el icor excelso de las flores insignes" ${ }^{18}$. Se debe recordar también el conocido poema "De blanco" de Gutiérrez Nájera, donde, a la manera de Théophile Gautier, hace una composición a base de objetos y seres blancos y puros que empieza con el verso "¿Qué cosa más blanca que un cándido lirio?" 19 .

La mujer lilial, virginal, etérea, más espíritu que materia, fue uno de los arquetipos femeninos recurrentes en el modernismo. Es la "Visión" del colombiano Julio Flórez:

¿Eres un imposible? ¿Una quimera?

¿Un sueño hecho carne, hermosa y viva?

¿Una explosión de luz? Responde esquiva

maga en quien encarnó la primavera.

Tu frente es lirio, tu pupila hoguera, tu boca flor en donde nadie liba

la miel que entre sus pétalos cautiva

al colibrí de la pasión espera ${ }^{20}$.

En la novela de José Asunción Silva, De sobremesa (1925), aparece Helena de Scilly Dancourt como una imagen prerrafaelita de pureza absoluta, caracterizada por el lirio blanco. Es la amada ideal, deseada e idolatrada, imaginada, soñada, casi vista. En el primer encuentro se vuelve levemente hacia José Fernández, el protagonista, pero no lo mira, como no miran a quienes las observan las mujeres de los cuadros, y ello produce en el

18 Rubén Darío, "De invierno”, en Azul (1888), ed. Madrid, Espasa Calpe, 1966, p. 147; y "El poeta pregunta por Stella”, en Prosas profanas, p. 75.

19 Manuel Gutiérrez Nájera, "De blanco" (1888), en Poesía, ed. Ángel Muñoz Fernández, México, Factoría Ediciones, 2000, p. 2777.

20 Aurelio Martínez Mutis, Julio Flórez. Su vida y su obra, Bogotá, Instituto Caro y Cuervo, p. 57. 
esteta "no sé qué extraña impresión de místico respeto irresistible", como si fuera la aparición de una virgen o una santa. Obsesionado por ella la ve incluso en sueños: "con un vestido cuya falda cae sobre los pies desnudos, en una orla de dibujo bizantino, de oro bordado sobre la tela opaca y llevando en los pliegues níveos del manto que la envuelve, un manojo de lirios blancos", al tiempo que escucha la música de un hexámetro latino: "Manibus date lilia plenis" 11.

La azucena, o lirio de la Anunciación, (lilium candidum) era la flor más pura, con atributos de majestad ${ }^{22}$ por la altura y castidad de sus pétalos blancos. Era el símbolo de la Virgen María, tal como aparece en el famoso cuadro de Dante Gabriel Rossetti Ecce Ancilla Domine! (1849-50), una radical reinterpretación del tema, con la virgen como una adolescente sorprendida y asustada ante el prodigioso acontecimiento que le anuncia el arcángel.

Por extensión, estas flores blancas se consideraron emblemáticas de la castidad de la doncella, atributo del amor y de inviolada pureza. Se asociaron con el arquetipo de la mujer virginal y delicada, que obsesionaría al fin de siglo. La vemos en El enemigo (1908), novela del modernista mexicano Efrén Rebolledo. Es Clara, el amor imposible del neurótico Gabriel, que, al igual que el marqués de Bradomín en la Sonata de primavera de Valle Inclán, imagina su pureza al verla con sus hermanas: "cuánta paz respiraría aquel convento habitado por sencillas y castas vírgenes, cuya vida era la delectación del Esposo. Todas habrían sido graves y muy bellas, pálidas y marchitas, como las azucenas que florecen a la sombra"23.

\section{La rosa}

Por su belleza y aroma, la flor más atractiva y de significados más complejos era la rosa. Del prerrafaelismo se acogió la tradición cristiana

21 José Asunción Silva, De Sobremesa (publicada póstumamente en 1925), en Obras completas, ed. Héctor Orjuela, Buenos Aires, Editorial Plus Ultra, 1968, II, p. 148.

22 Continuando la tradición que deriva de Hera, la diosa mitológica y reina del Olimpo, se cuenta que, estando dormida, Zeus colocó en su seno a Heracles, su hijo ilegítimo, para que se alimentara. Unas gotas de leche cayeron en el cielo y formaron la Vía Láctea, otras rodaron por la tierra y de allí brotaron los lirios.

23 Efrén Rebolledo, Obras Completas, México, Editorial Cultura, p. 147. 
que compara a María con una rosa sin espinas y su lugar entre las mujeres como la rosa entre las flores, y del legado medieval llegó su simbolismo relacionado con el amor. Son numerosas las comparaciones de la mujer con esta flor, de sus labios con pétalos rojos, de su sexo con la corola abierta. Otros significados variaban con el color, belleza, lozanía, desde la conocida identificación que Martí establece entre la rosa blanca y la amistad en el sistema de correspondencias cromáticas de sus Versos sencillos (1891), hasta los pequeños poemas de "Elogio de las Rosas" de Lugones, su "Lied de la boca florida", que incorpora el fondo medievalizante, y "El amor eterno", donde representa distintas etapas de la pasión; las rojas son "ardientes como llamas"; otras, en cambio, "mejor perfuman cuando son tardías" 24 .

En el modernismo desaparece casi completamente la representación naturalista y la imagen, además de su dimensión estética, es un comentario simbólico. En "Visión” Rubén Darío se inspira en Dante y se refiere su extremo anhelo de lo absoluto: "albas eternas se abre al infinito / la sacrosanta rosa de las rosas" 25 . En "Yo persigo una forma", de Prosas profanas, la aspiración del botón del pensamiento que busca ser la rosa sugiere el esfuerzo de su imaginación poética. El poeta es el intérprete de los enigmas del mundo, y la rosa le revela el misterio. Reconoce en una anciana a un hada que declara: "Mira esta rosa seca, ella en mis labios pone la mágica armonía”26. En Canto a la Argentina, postula el sacrificio de la rosa niña, que, llevada por los reyes magos ante el pesebre, no halló que darle al Niño Jesús sino ella misma transformada en rosa, como inmolación de la feminidad ante el dios generador: "Se fue convirtiendo poco a poco en rosa, / en rosa más bella que las de Sharón"27. También Darío amplifica y universaliza el erotismo como embriaguez rapsódica

24 Leopoldo Lugones, "Elogio de las rosas", en Obras poéticas completas, Madrid, Aguilar, 1974, pp. 654-66; "Lied de la boca florida", ibidem, pp. 781-782; y "El amor eterno", ibidem, p. 701.

25 Rubén Darío, El Canto Errante, Buenos Aires, Espasa-Calpe, 1945, p.70. Sobre este tema cf. Jaime Giordano, La edad del ensueño. Sobre la imaginación poética de Rubén Darío, Santiago de Chile, Editorial Universitaria, S.A., 1971.

26 Rubén Darío, "Palabras de la satiresa", en Prosas Profanas, p. 77.

27 Rubén Darío, Canto a la Argentina y otros poemas, en Poesías completas, ed. Alfonso Menéndez Plancarte, Madrid, Aguilar, 1961, p. 954. 
del universo: "Pues la rosa sexual / al entreabrirse / conmueve todo lo que existe. / Con su efluvio carnal. / Y con su enigma espiritual"28.

\section{EROS Y TÁNATOS}

La sucesión de flores en los ciclos de la naturaleza refieren al transcurso de la vida humana. Nervo nota que las violetas, "tímidas y lánguidas", ya al final del invierno van desapareciendo. En cambio, con la energía desbordante y el erotismo fecundo de la primavera, lucen las rosas encendidas; "rojas y frescas como femeniles bocas" y flores de pétalos blancos y carnosos que hacen pensar "en las desnudeces de raso, en carnes sonrosadas y transparentes" 29 .

En la pintura modernista puede verse esa relación cíclica a través de la actualización de la antigua tradición iconográfica con personificaciones alegóricas ${ }^{30}$. Alfredo Ramos Martínez escoge el tema del despertar erótico de la mujer en La primavera (1905), con un cuarteto de muchachas con ramilletes de rosas en las manos, y una más joven, apenas formando el suyo. Ya en Flora (La ninfa del manantial) (1910), Francisco Romano Guillemín presenta una hermosa y fecunda mujer desnuda que cierra los ojos y extiende el brazo derecho con gesto voluptuoso. Está tendida en un edénico prado florecido con lirios y calas de grandes pistilos fálicos.

La mujer es identificada con las flores, caracterizada por ellas e inclusive, como en la joyería de Lalique, funde su cuerpo con las líneas sinuosas del tallo o la corola. Saturnino Herrán personifica con el título de su óleo, Bugambilias (1911), a una mujer, en un prado densamente rameado, que echa hacia atrás la cabeza con alegría salvaje para aspirar con fruición la vida.

De sobremesa presenta una galería de retratos de mujeres-flores, relacionadas con José Fernández. Helena, la amada ideal, es la mujer

28 Rubén Darío, Cantos de Vida y esperanza. Los cisnes y otros poemas, en Poesías completas, p. 761.

29 Amado Nervo, "La Semana", El Mundo, 21 de agosto de 1898, en Las ciudades del cronista. Ciudad de México, http://www.amadonervo.net/ciudades/mexico/ sc/21ago98.htmlp. 20.

30 Sobre este tema cf. Fausto Ramírez, "El simbolismo en México", en El espejo simbolista, Europa y México, 1870-1920, Museo Nacional de Arte, 2004, pp. 29-59. 
lirio. Más sensuales son María Legendre, refinada hedonista con perfil de Diana cazadora, caracterizada por su perfume a magnolia. Consuelo es el amor de la infancia, una "virgen vestida de muselina blanca" a quien regala las flores del ayer, las "orquídeas parásitas rosadas de Guaimis"; y Nelly, la americana, es "una flor de carne acabada de abrir".

Las referencias eróticas florales de todo tipo abundan en la poesía modernista. Julián del Casal refiere el desfloramiento de una doncella, con la fastuosidad que tanto admiraba: en el "lecho de marfil, sándalo y oro / en que deja la virgen hermosura / la ensangrentada flor de su inocencia" 31 . Y Lugones recurre en "La alcoba solitaria" a la magnolia para referirse al cuerpo de la mujer:

No quedaba de ti más que una gota

de sangre pectoral, sobre la rota

almohada. El espejo opalescente

estaba ciego. Y en el fino vaso,

como un corsé de inviolable raso

se abría una magnolia dulcemente ${ }^{32}$.

La textura carnosa y la blancura aterciopelada de esta flor propiciaban su asociación con el cuerpo femenino. José Santos Chocano indica su "fina redondez a manera / de una dama que luce descotado seno" ${ }^{33}$. Darío asigna alusiones eróticas a "las altas magnolias", que con las rosas y lilas primaverales forman parte del sensual decorado de la fiesta galante de "Era un aire suave".

Se debe mencionar a Delmira Agustini, quien transformó el discurso modernista masculino del deseo y del placer en imágenes atrevidas y poco convencionales para su tiempo. Desde El libro blanco (1907), con descripciones de cisnes y lagos, flores de loto y jardines perfumados; y sobre todo en libros posteriores como Cantos de la mañana (1910) y Los cálices vacios (1913), donde hace gala de un vocabulario metafórico de intenso erotismo. Ante su amado su mirada es:

31 Julián del Casal, "Mis amores. Soneto pompadour", en Poesías completas, p. 77.

32 Leopoldo Lugones, op. cit., pp. 122-123.

33 José Santos Chocano, “La magnolia”, en Obras Completas, Madrid, Aguilar, 1954, p. 410. 
...una culebra

glisando entre los riscos de la sombra

a la estatua de lirios de tu cuerpo.

Tú te inclinabas más y más... y tanto,

$\mathrm{y}$ tanto te inclinaste,

que mis flores eróticas son dobles,

y mi estrella es más grande desde entonces ${ }^{34}$.

Agustini revela su feminidad, “¡su cuerpo excelso derramado en fuego / sobre mi cuerpo desmayado en rosas!", y adopta la imagen erotizada de la flor que se abre y se entrega en el rito del amor:

La eléctrica corola que hoy despliego brinda el nectario de un jardín de Esposas;

para sus buitres en mi carne entrego todo un enjambre de palomas rosas ${ }^{35}$.

Al final del ciclo de la vida, la muerte es ineludible. Amado Nervo, cuando ya no encuentra las rosas ardientes que había admirado, se pregunta dónde está el cementerio de las flores, pues solo ha quedado de ellas una estela de perfume marchito. Y el pintor mexicano Saturnino Herrán, en La ofrenda (1913), a modo de un Böecklin mexicanizado, abre la puerta al reino de tánatos. En los antiguos canales del valle de México, unas trajineras o canoas van cargadas con zempasúchil, la flor amarilla que se coloca sobre los altares y tumbas los días de difuntos.

La muerte podía ser reinterpretada a través de creencias esotéricas y ocultistas que circulaban en el cambio de siglo. En "Responso", Rubén Darío, ante la tumba de Verlaine, expresa una serie de deseos en términos florales: "Que tu sepulcro cubra de flores Primavera, / que se humedezca el áspero hocico de la fiera / de amor si pasa por allí; / que el fúnebre recinto visite Pan bicorne; / que de sangrientas rosas el fresco abril te adorne / y

34 Delmira Agustini, "Visión," en Poesías Completas, ed. Alejandro Cáceres, Montevideo, Ediciones de la Plaza, 2006, p. 271.

35 Delmira Agustini, "Otra estirpe", ibidem, p. 277. 
de claveles de rubí”36. Una corriente animista recorre el poema; el poder germinativo de las plantas viene del cuerpo que está ya en la tierra y del alma que lo preside. Verlaine queda situado al nivel de Pan, el gran Todo de los neoplatónicos, provocador de la celeste unidad a través de los ciclos de la vida y de la muerte. En esos versos expone la significación de Pan, por él se exalta la vida a través de las flores, de la primavera, de la música, del amor sobre el sepulcro del poeta, a pesar de la muerte, y más aún, por la misma muerte, que es condición esencial para el renacimiento.

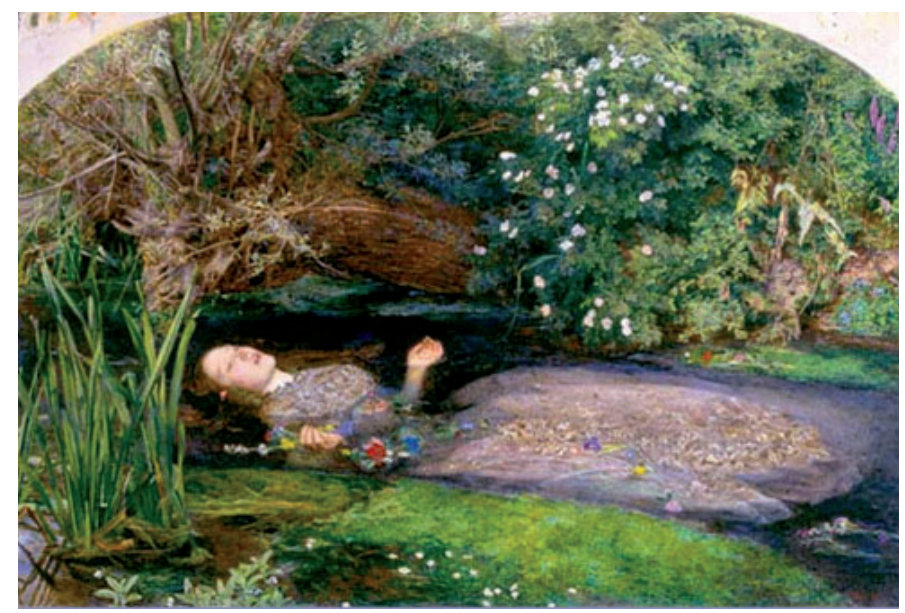

John Everet Millais, Ophelia (1851-2). Tate Gallery, Londres.

\section{De Ofelia a Salomé}

El cerebralismo y la misoginia del decadentismo inspiraron extravíos donde se mezclaban obsesiones de erotismo libertino y pensamientos místicos. La castidad no disminuía, sino que atizaba el deseo, y por ser prohibido, el pecado era el máximo placer. Pero en esos éxtasis celestiales y malditos se llegaba a la conclusión de que la castidad, tanto como el sexo, implicaba la mortalidad, la muerte y la podredumbre de la carne ${ }^{37}$.

36 Ruben Darío, Prosas profanas, p. 103.

37 Sobre este tema cf. mi libro Erotismo fin de siglo, Barcelona, Antoni Bosch, 1979. 
En su búsqueda de lo anormal y del sadismo, para estimular tanto la imaginación como la búsqueda de nuevos valores estéticos, se impuso el tema de las jóvenes tuberculosas, suicidas, agonizantes, ahogadas, muertas $^{38} \ldots$ Y la doncella muerta a destiempo más celebrada por el modernismo fue Ophelia, tal como figuraba en el cuadro de John Everet Millais, tan comentado desde que fue exhibido en la Royal Academy en 1852. Hay que recordar que el pintor pasó varios días junto a un río para retratar con exactitud las flores y plantas de sus márgenes ${ }^{39}$, y que esta obra popularizó las flores primaverales o silvestres: la prímula, la lila, la violeta,

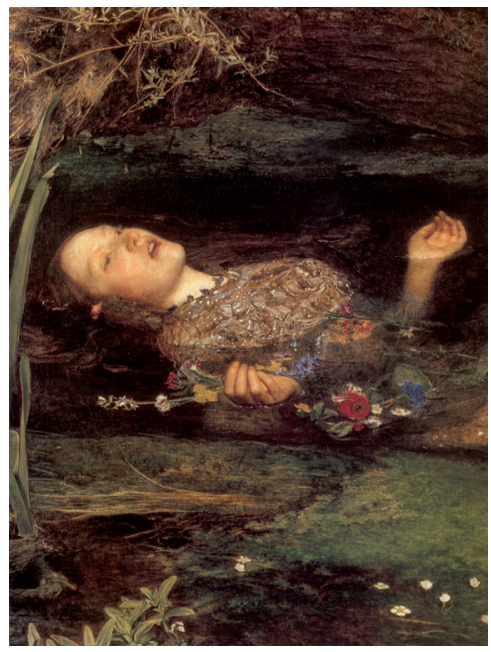

Ophelia, detalle.

el pensamiento, la margarita cuyos tonos pálidos y delicados evocaban el primer sonrojo de la belleza femenina y la edad en que la joven se convierte en mujer. Millais se había inspirado en la escena del Hamlet de Shakespeare, y eligió el tema del amor y la muerte en el suicidio de Ofelia, que aparece flotando en las aguas de un riachuelo, engalanada con unas guirnaldas sobre su cuerpo y sosteniendo unas flores en una mano.

38 Cf. Bram Djikstra, Ídolos de perversidad. La mujer en la cultura de fin de siglo, Madrid, Debate, 1994.

39 Danielle Bruckmuller-Genlot, Les Préraphaélites. 1848-1884, Paris, Armand Colin, 1994, pp. 36, 237, 250 y 326. 
El cuadro es descrito en De Sobremesa, y reinterpretado por Silva al referirse a María Bashkirtseff, una joven pintora simbolista rusa que había muerto el último día de 1884 . Silva la había conocido a través de Barrès, y había quedado tan impresionado por ella que la introdujo en la novela. El protagonista, el esteta decadente José Fernández, la contempla tocando el piano, y al escuchar el doliente nocturno, la imagina arrastrada por el río, pálida y rubia, coronada de flores, como la Ofelia del cuadro de Millais. Sus rasgos, atuendo y pose son similares; la tez aterciopelada, la espesa cabella extendida en graciosa curva sobre el agua, y el vestido de crespón de seda rosado, adornado con una guirnalda de rosas de bengala. Será para él la virgen muerta más ideal, que "encerraste en los límites de la obra de arte soñada y diste en un libro la esencia de tu alma" ${ }^{40}$.

Otras jóvenes-lirios son más perversas, y algunas también fatales. En la novela Sangre patricia (1902) de Manuel Díaz Rodríguez es Belén Montenegro quien muere joven y desde la tumba se aparece como un lirio inmenso a su amado Tulio y lo lleva a la muerte. Una inocente flor es centro de ambigüedad en "Margarita", de Prosas profanas: Recuerda el poeta a la amada, de extraño rostro, que en la noche alegre de la primera

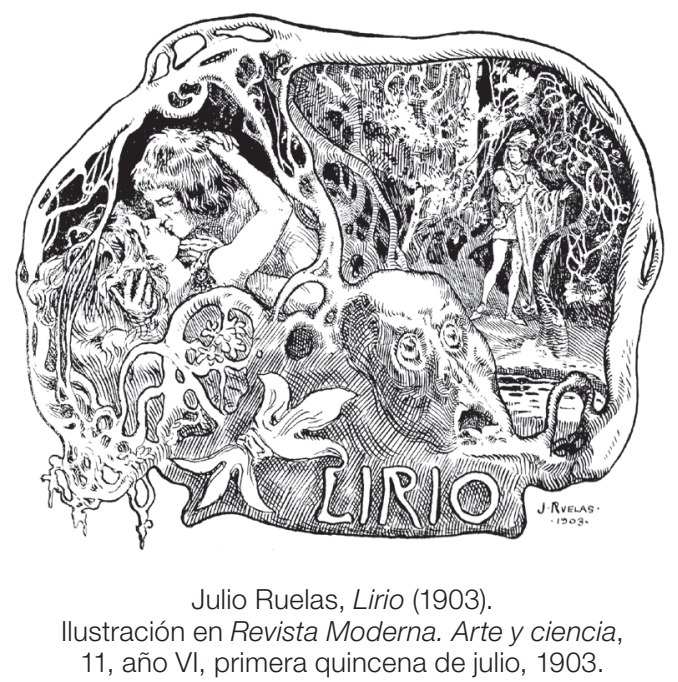

40 José Asunción Silva, op. cit., p. 29. 
cita quería ser una Margarita Gauthier: "Tus labios escarlatas de púrpura maldita / sorbían el champaña del fino baccarat; / tus dedos deshojaban la blanca margarita, / «Sí... no... sí... no...» ¡y sabías que te adoraba ya!”¹. Pero el significado tradicional de deshojar la margarita, para ver si se es correspondido en el amor, se convierte en un destino trágico: es la muerte quien gana, y la joven muere de tisis. El poeta ha venido preparando el inesperado final, al calificar como "púrpura maldita" la boca de la mujer que no es solo sensual, sino perversa, pues disfraza la enfermedad que la carcome. El desenlace ha aumentado los gozos del amante, pues con esa belleza manchada posee el ambiguo placer del amor y la muerte.

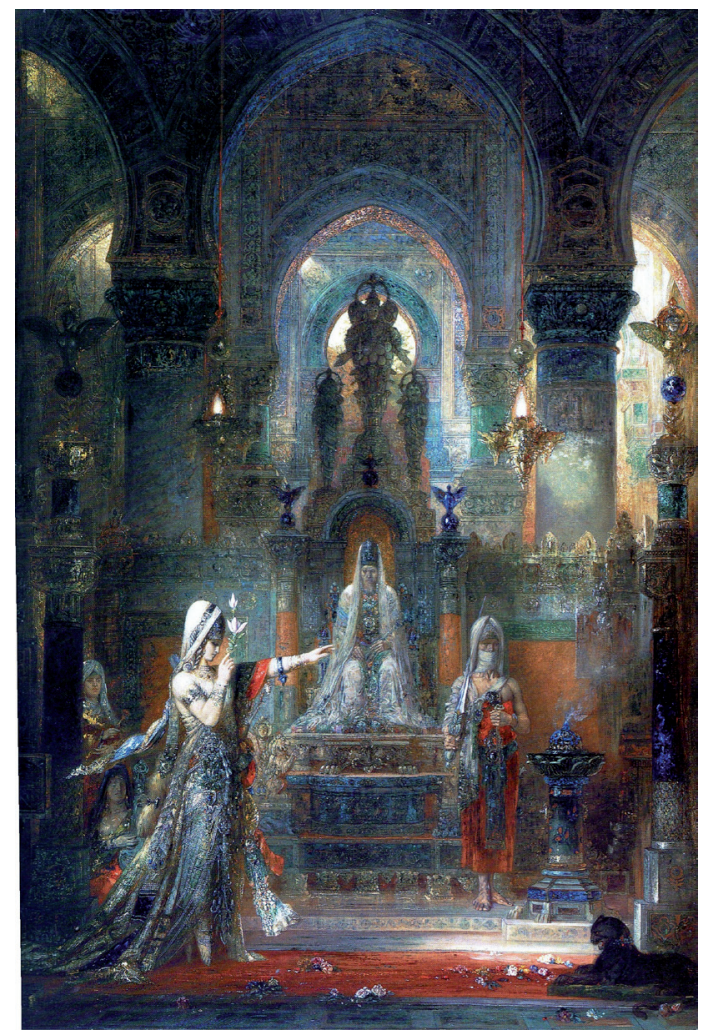

Gustave Moreau, Salomé (Salomé bailando ante Herodes) (1874-76).

The Armand Hammer Collection: Armand Hammer Museum of Art and Culture Center, UCLA, Los Ángeles.

41 Ruben Darío, op. cit., p. 52. 
En la obra de Julio Ruelas la mujer es emblema de una desencadenada vitalidad genésica, arrebatada por impulsos sexuales; un ser irracional, unida a la animalidad y a regresión a la materia. En sus viñetas y letras capitulares para La Revista Moderna las figuras humanas quedan aprisionadas entre cabelleras femeninas, confundidas con raíces y ramas arbóreas que sugieren el enraizamiento en los instintos y en la tierra. Un buen ejemplo es la viñeta para el poema "Lirio", de Manuel Machado $(1903)^{42}$, con una pareja de amantes recostados en medio de un bosque, enlazados con el mundo vegetal circundante. Ya forman parte del remolino de raíces que dan sustento a los árboles, y de allí brota una calavera con una anamórfica flor de lis.

El arquetipo opuesto a la mujer-lirio es la mujer fatal, bellísima, de cuerpo histérico y alma de ninfómana, que en sus excesos de lujuria doblega a sus amantes. Su crueldad se asocia con flores diversas y a veces con el solo gesto definitorio de deshojar una flor, como la "divina Eulalia de "Era un aire suave", la "Eva”, de José Martí, y Noemí, la pálida pecadora de Julián del Casal; es la belle dame sans merci de temperamento frígido que hace sufrir y esclaviza a los hombres sin que ella se conmueva.

Más precisa es la asociación de esta figura con flores malignas de colores extraños. En Salamandra (1917), de Efrén Rebolledo, Elena Rivas aparece descrita en un espacio aristocráticamente perverso, recostada en un diván cubierto por una piel de tigre, y a su lado "un ramillete de rosas tintas, que parecía un ramo de corazones chorreando sangre". Sus cabellos, que ahorcarán al desdichado que se enamora de ella, son "tan negros y perfumados que sugerían la maravilla de un ramillete de rosas negras" ${ }^{43}$.

Este arquetipo encarnó para los modernistas en las famosas mujeres fatales de la historia y la leyenda: Circe, Dalila, Helena, Medea, Lilith... y sobre todo, realzada por un marco de exotismo, en Salomé, que pidió como recompensa por su danza la cabeza del Bautista. Éste fue el tema de los famosos cuadros de Gustave Moreau Salomé (1874-76) y La Aparición (1874-1876), que habrían de convertirse en modelos privilegiados para los simbolistas, con el apoyo de las descripciones y comentarios que de ellos hizo Huysmans en su gran novela de la decadencia: $\grave{A}$ Rebours (1884).

42 Manuel Machado, Revista Moderna, VI (11 junio de 1903), p. 164.

43 Efrén Rebolledo, Salamandra, en Obras Completas, pp. 254 y 257. 
La imagen de la bailarina semidesnuda, y tatuada, con el cuerpo cubierto de joyas, encarnación suprema de la "luxure" con su encanto de gran flor perversa, nacida en bancales sacrílegos, criada en invernaderos impíos" ${ }^{44}$, se difundió en Hispanoamérica, inspirando, entre muchos otros, a Rubén Darío, Gómez Carrillo, Delmira Agustini, Rafael López y a Julián del Casal, cuyo poema "Salomé" apareció en La Habana Elegante $(1890)^{45}$.

El poeta cubano reconstruye la exótica sala del palacio de Herodes, "el calado techo" y "la anchurosa nave"; diseña la figura decadente del tetrarca, adormecido, extenuado, hierático. Aunque inspirado por la descripción de Huysmans, adopta el estatismo del cuadro de Moreau. El poema termina con la imagen de Salomé detenida en el tiempo: “y en la diestra alzado, / muestra siempre, radiante de alegría, / un loto blanco de pistilos de oro".

Se puede ver la importancia que tiene la flor en el poema. Es emblemática de Salomé y de toda la sádica escena. Huysmans opinaba que Salomé era inasible para los espíritus precisos y prosaicos, e incomprensible para los pintores y escritores que jamás habían podido reproducir la exaltación de la bailarina, la grandeza refinada de la asesina. Solo en la obra de Gustave Moreau, concebida fuera de todos los datos del Testamento, el protagonista de su novela, des Esseintes, el esteta decadente que encontraba placer en el artificio y despreciaba la vida y las costumbres de su tiempo, veía al fin realizada a Salomé. Ya no era simplemente la danzarina que había doblegado la voluntad de un rey. Era la deidad simbólica de la indestructible Lujuria, la diosa de la inmortal Histeria. Opinaba que el pintor había podido permanecer fuera de los siglos, al no dar precisiones sobre origen, país, o época, colocando a su Salomé en ese extraordinario palacio, de un estilo confuso y grandioso, ataviándola con suntuosos y quiméricos vestidos, colocándole, a modo de mitra, una incierta diadema en forma de torre fenicia, y por fin, poniéndole en la mano el gran loto, el cetro de Isis, la flor sagrada de Egipto y de la India.

Des Esseintes buscaba el sentido de ese emblema, preguntándose si

44 Para esta y las demás citas y comentarios de Joris-Karl Huysmans, A Rebours, Paris UGE, 1975, a los cuadros de Moreau, cf. el capítulo 6 de su famosa novela.

45 Julián del Casal, "Salomé”, en "Mi museo ideal (Diez cuadros de Gustave Moreau)", en Nieve. Poesías Completas, p. 165. 
tendría el sentido fálico que le habían atribuido los cultos primordiales de la India o si le anunciaba al viejo Herodes una oblación de la virginidad bajo la condición de un crimen. Si sería una alegoría de la fecundidad, o representaba el mito hindú de la vida. Pensaba que acaso el pintor estaba aludiendo a las ceremonias sepulcrales de embalsamamiento en el antiguo Egipto, cuando los sacerdotes purificaban los órganos sexuales de los muertos insertándoles los castos pétalos de la divina flor.

El loto del cuadro interesó a Mario Praz, y a Lezama Lima, quien también analiza su papel en el poema de Julián del Casal ${ }^{46}$. Ambos concordaron en cierta forma en el significado fálico del loto, y en el hecho de que al identificarse con el centro místico de Oriente, invertía, de manera blasfema, las connotaciones que en Occidente tiene la rosa, identificada con la Virgen María. En ese contexto, la flor era símbolo de una religión regida por la lujuria y la muerte y anunciada por la bailarina, que era, según como la describe Huysmans, "la belleza maldita, deidad simbólica de la indestructible Lujuria, que pertenece a las teogonías del Extremo Oriente" ${ }^{47}$.

\section{DECADENTES, REFINADOS Y NEURÓTICOS}

Algunas flores estaban dotadas de las fuerzas oscuras de la naturaleza. Por ejemplo la flor del acónito, de color azul o violeta, tan venenosa que antiguamente se usaba para envenenar las flechas. Rafael López, en su poema "Ruelas", exalta al pintor como artista "iluminado", por el diablo, y por medio de este símbolo se refiere a sus representaciones de la mujer; satánica y portadora de la muerte:

46 Mario Praz, The Romantic Agony, Nueva York, Meridian Books, 1956, p. 293. Lezama Lima comenta una escena en la que la imagen triunfal de Salome, "radiante de alegría", alza el loto y lo transforma, con ese gesto, en la imagen del deseo en función de una serie 'loto/lirio/cabeza/maza', de cuyo impulso sustitutivo depende el despliegue encadenado de los sonetos "La Aparición" y "Salomé". Cf. José Lezama Lima, "Julian del Casal", Analecta del reloj, en Obras completas, Madrid, Aguilar, 1977, II, p. 71.

47 Joris-Karl Huysmans, op. cit., p. 117. 
Taciturna y maligna, tu flotante quimera tiene pechos de esfinge, de mujer la cadera, y a la flor del acónito huele su cabellera ${ }^{48}$.

Tan incomprensible como peligrosa, la carnívora diónea fascinó a la época. Su nombre común, "trampa de Venus", la refería a la falsedad de la mujer, y emblematizaba sus maquinaciones y el mal de la seducción. De manera traidora se abría, enseñado a las incautas moscas su "seno de carmín”, y tragaba a su víctima cerrando sus dos pétalos verdes como si fueran dientes ${ }^{49}$. Otras flores escondían su malevolencia tras su belleza, como la adelfa, poderoso emblema funerario, por ser su savia y hojas fuertemente venenosas. En un poema, Julián del Casal la proyecta contra la azucena:

Mi corazón fue un vaso de alabastro

donde creció, fragante y solitaria, bajo el fulgor purísimo de un astro una azucena blanca: la plegaria.

Marchita ya esa flor de suave aroma, cual virgen consumida por la anemia, hoy en mi corazón su tallo asoma una adelfa purpúrea: la blasfemia ${ }^{50}$.

El artificio era para los decadentes una marca del ingenio creativo humano y elemento estético primordial, superior a las producciones de la naturaleza. Por ello admiraban las flores vivas que parecen artificiales, las que parecen artificiales pero están vivas, y aquellas ideadas por el arte, más bellas e imaginativas que cualquiera producida por la naturaleza. Es la inspiración del curioso poema que Casal dedica al rey Luis II de Baviera,

48 Rafael López, Con los ojos abiertos (1912), en Antología del Modernismo, ed. José Emilio Pacheco, México, UNAM, 1970, II, pp. 107-108.

49 José Martí, "La Exhibición de flores". Escenas de Estados Unidos, redactadas el 28 de noviembre de 1890 en Nueva York y publicadas en La Nación el 11 de enero de 1891: http://www.damisela.com/literatura/pais/cuba/autores/marti/ usa/1890_11_28.htm.

50 Julián del Casal, "Flores", en Poesías Completas, p. 213. 
uno de los iconos del fin de siècle, "Flores de éter" ${ }^{51}$, título simbolista tanto por la imagen como por la referencia a la droga, tan consumida por entonces. Del mismo autor es el cuento "La cámara de las torturas", donde presenta una biblioteca, iluminada por un mortecino cirio. Llama la atención sobre una colección de raras flores malsanas y perversas que la naturaleza sería incapaz de engendrar. Tejidas en la alfombra roja, "mandrágoras, euforbios, eléboros, y toda suerte de plantas letales". En esa negación sádica de la naturaleza, completa el decorado con una red inmensa trabajada con gran arte que cubre las vigas del techo y muestra a su vez "flores monstruosas, quiméricas, extravagantes y amenazadoras" 52 . Interesa señalar en esta narración otro tema característico del decadentismo. El lector ha llegado a este recinto siguiendo los pasos de un ambiguo y bello joven, que en algo recuerda a Dorian Gray. Está vestido con extrema elegancia, y muestra un pliegue desdeñoso y hastiado en sus delgados labios. A su paso deja una estela de intenso y singular perfume, mezcla de templo y de lupanar, "que parecía combinado con granos de incienso y con flores de reseda" 53 .

La detallada mención al perfume que hace Casal no es anodina ni debe pasar desapercibida. Desde Baudelaire, y a través de los poetas malditos, se habían exaltado las sensaciones que producen los perfumes, "porque despiertan en nosotros más que otras [sensaciones] algo inefablemente oscuro y triste que llevamos dentro de nosotros" 54 . Paul Bourget también había comentado la extravagancia de la inspiración de los decadentes no espontánea y natural, sino artificiosa y especialmente ávida, "de buscar flores desconocidas y perfumes [...] no respirados antes" 55 . Delmira Agustini recurre a menudo a aromas peregrinos que asocian el estado de ánimo con el perfume de una flor. En "La musa gris”, la inspiración "tiene un perfume de tristes violetas", y en "Flores vagas" unas extrañas

51 Julián del Casal, ibidem, p. 227.

52 Julián del Casal, "El amante de las torturas", en Prosas I, La Habana, Consejo Nacional de Cultura, 1963, p. 236.

53 Julián del Casal, ibídem, p. 236.

54 Paul Bourget, Essais de Psychologie Contemporaine, Paris, Plon-Nourrit, 1901, I: "parce qu'elles remuent plus que les autres ce je ne sais pas quoi de sensuellement obscur et triste que nos portons en nous" (p. 24).

55 Paul Bourget, ibidem, p. 20. 
flores opalinas, despiden dos perfumes: "Uno que es mirra y miel de los sentidos / y otro grave y profundo que entra al alma"56.

Otro ejemplo se encuentra en uno de los poemas más hermosos de Silva, el "Nocturno II". Consta de tres estrofas, cada una portadora de un recuerdo de la mujer amada: los "besos furtivos" en la oscuridad de la selva, los besos íntimos en el lecho de una alcoba, y el último beso, con ella muerta y yaciendo en un ataúd. El perfume de la reseda es el hilo conductor del recuerdo y de la memoria atormentada del poeta. Aparece en cada una de las tres escenas y con la mayor intensidad al acompañar a la muerte. "Inquietos, refinados, perversos, escépticos, enfermizos" 57 , había llamado Gómez Carrillo a los decadentes, entusiastas de lo nuevo y de lo exótico, "almas complejas", por su afición a las coloraciones raras, a los perfumes enervantes, a su seducción por las orquídeas que parecen flores artificiales $^{58}$. Esta flor, de complicada forma lleva al mundo de Huysmans y de Maeterlinck, quien en su sorprendente libro La inteligencia de las flores definía a las orquídeas como "las manifestaciones más perfectas y más armoniosas de la inteligencia vegetal. En esas flores, atormentadas y extrañas, el genio de la planta alcanza sus puntos extremos, y viene a penetrar, con una llama insólita, la pared que separa los reinos" 59 . Se refería a ciertas orquídeas que toman la apariencia de insectos, e inclusive exhalan su olor con el fin de atraer a un polinizador para reproducirse. Se justifica así que "hacer Cattleya" haya aparecido en la gran novela de Proust como metáfora de la posesión física para Odette y Swan. Sabemos también que Proust conservó hasta su muerte el retrato que le hizo Jacques-Emile Blanche, donde se ve al joven Marcel, de frente, en pose hierática, y en contraste con su oscuro traje lleva una orquídea blanca en la solapa.

A pesar de que esta parásita no es exótica sino oriunda en diversas partes de América, posiblemente por influencia europea, también fue valorada por los modernistas. Santos Chocano admira sus "enigmáticas

56 Delmira Agustini, op. cit., pp. 141 y 143.

57 Enrique Gómez Carrillo, Literatura extranjera. Estudios cosmopolitas, París, Librería de Garnier Hermanos, 1895, p. 139.

58 Enrique Gómez Carrillo, ibidem, p. 306.

59 Maurice Maeterlinck, La inteligencia de las flores, Buenos Aires, Ediciones CHACO, 1974 , pp. 45-53. 
formas sorprendentes", su equilibrio en los árboles y ensortijadas raíces, "libres de ligaduras con la tierra" $"$. En De Sobremesa, Consuelo, la amante colombiana de Fernández en París, le recuerda que todo lo que los europeos aman en exceso, oro, esmeraldas, café, orquídeas les llega de Colombia. Y el esteta comparte el estado de hiperestesia de Des Esseintes, así como su predilección por las “orquídeas monstruosas", que mantiene en un vaso de antigua mayólica sobre su escritorio, al lado de una heteróclita colección de objetos que denotan su sofisticación y extremo refinamiento ${ }^{61}$. Hay que recordar que Silva, durante su estancia en París conoció a Mallarmé, y de vuelta a América, desde Caracas, envió a su admirado amigo y maestro una planta de orquídea, especialmente preparada para que sobreviviera al largo viaje transatlántico ${ }^{62}$.

José Martí describe detenidamente una exposición de orquídeas. Indica la peculiar forma de vida de esas "parásitas encantadoras" que no parecen flores naturales, sino artificiales, y describe admirativamente varias especies, citándolas con su nombre botánico, lo cual las hace más enigmáticas e incomprensibles para el no iniciado. Menciona el odontogloso tigrado, el encidio, el cigopétalo, el dendrobio, el cattleya rosa y lila, con el labio de oro puro, la almodiana de flores refulgentes como mariposas heladas. Comenta más detenidamente los cyripendios. Probablemente influido por el libro de Maeterlinck, reconoce la inteligencia de esas flores, visible en sus artilugios. En su extraño labio colgante ampara "de los insectos ladrones" los granos de polen "que le trae en el lomo la abeja buscamieles, enamorada de la fragancia y el color" para permitir que en su estigma, que se prolonga tubos abajo, "se junten con el huevo"63. La planta es hábil en verdad o tiene pensamientos, pues "echa listas de carmín a lo largo de sus tres pétalos blancos, y bruñe hasta que da luz su zapatilla redonda para que la visite la abeja”. Y tiene otras estrategias; cría crines por el borde interior de su "zapatín" para que se le traben las patas al mosco que viene a beberse la miel, y su tallo peludo, y el barniz de la flor la protegen que no se le suba la hormiga venenosa. Por ello se pregunta el escritor si la

60 José Santos Chocano, op. cit., p. 402.

61 José Asunción Silva, op. cit., p. 129.

62 Juan Loveluck, "De sobremesa, novela desconocida del modernismo", Revista Iberoamericana, XXXI, 59, 1965, pp. 17-32, p. 112.

63 Jose Martí, "La Exhibición de flores". Escenas de Estados Unidos. 
orquídea “ ¿es alma en ciernes que sabe menos que el hombre o es alma en pena, ya a punto de vuelo, que purga en la pelea -hermoseando, como todo lo que padece- sus últimas culpas?”.

Podemos concretar ciertos puntos para completar lo anteriormente expuesto. Las flores esenciales en la escritura poética del modernismo son antinaturalistas. Encarnan el giro por el cual se abandona la naturaleza prolífica y creadora, la natura naturans del poeta romántico, y se convierten en símbolos de la naturaleza en estado artístico ${ }^{64}$. Muestran la nueva conciencia formal del Parnaso a través de sus formas ricas y complejas que deslumbran por su hermosura o peculiaridad.

Por su carácter simbolista, las flores modernistas incorporan una tercera dimensión a la obra. Además de ser contempladas, deben ser interpretadas. Tienen más valor por sus significaciones y símbolos ocultos que por su función natural. Debido a ello, a menudo adquieren una jerarquía mitologizante.

Son notables las características intertextuales e interdisciplinarias de las flores modernistas, que pueden ser inventadas, imaginadas o elaboradas a través de libros y obras de arte. Esta relación con diversos discursos literarios o visuales no es solamente una preocupación "museística”. Como indica Yurkievich, el modernismo tiene verdadera avidez por una cultura periférica, anhela apropiarse del legado de todas las civilizaciones en todo lugar y en toda época, de allí la heteróclita mezcla de ingredientes que acumula $^{65}$. Sin embargo, somete ese material a una experta formalización, pues exalta la perfección formal como el tributo más específico del arte. Inclusive, como se ha señalado, por ejemplo con el loto de Salomé, las implicaciones de esas lecturas o pinturas aleatorias modifican la propia creación, que se convierte en un palimpsesto con capas sobrepuestas de significados.

64 Cf. Hans Robert Jauss, "El arte como anti-naturaleza. El cambio estético después de 1789", en Las transformaciones de lo moderno. Estudios sobre las etapas de la modernidad estética, Madrid, Visor, 1995, pp. 117-124.

65 Saúl Yurkievich, Celebración del Modernismo, Barcelona, Tusquets, 1976, p. 3. 
La comunión de temas o referentes en distintos ámbitos culturales lleva a la idea simbolista de la correspondencia de forma de expresión. La lección de Wagner llegó hasta el simbolismo, cuyos teóricos y artistas siempre manifestaron interés en esas correspondencias. Basta citar algunos encuentros: Huysmans, entusiasmado con Moreau, Redon y Rops, en cuyas imágenes encontraba el reflejo de su propio satanismo; Mallarmé, que admiraba a Wagner menos como músico que por los nuevos sentidos que aportaba a través del uso simultáneo del texto y el sonido; Albert Aurier, que describió a Van Gogh como simbolista y afirmaba que en su pintura, bajo la superficie material, se encuentra, para la mente que sabe buscarlo, un pensamiento, una idea.

Entre esas menciones se debe señalar el lugar privilegiado que ocupa el arte en la obra de Rubén Darío, quien dedica muchas páginas a pintores: Böcklin, Velázquez, Fra Angelico, Puvis de Chavannes... Pero su deseo de exploración de formas va más allá de las simples referencias. Como se puede comprobar a través de la sección "En busca de cuadros" de $A z u l$, Darío se incorpora a la antigua discusión de ut pictura poesis, tratando de competir con la pintura ${ }^{66}$. Su "Naturaleza muerta" es un ingenioso acertijo que revela, más que su admiración por la pintura holandesa del siglo XVII, ciertas premisas esenciales del modernismo. Para descifrarlo, es preciso entender, en esa breve prosa, el significado de las lilas recién cortadas y de las esponjadas rosas de té ${ }^{67}$.

66 Cf. mi conferencia "Rubén Darío y la obra de arte", dictada el 20 de abril de 2006 en la Universidad Nacional Autónoma de México: www.amadonervo.net/transmigraciones/pdf/dario.pdf

67 Cf. el ensayo "Una naturaleza muerta, Rubén Darío derrota a Zeuxis y a Parrasio" en mi libro Imágenes y textos. Estudios sobre literatura y pintura. 1849-1936, Ámsterdam, Atlanta, 1998, pp. 33-35. 